\title{
EKSEKUSI HAK JAMINAN DALAM PENYELESAIAN KREDIT MACET \\ PADA PT BANK PERKREDITAN RAKYAT (BPR) SOLIDER PANCUR BATU KABUPATEN DELI SERDANG
}

\author{
Elisabeth Nurhaini Butarbutar \\ Fakultas HukumUniversitas Katolik Santo Thomas,Medan, Indonesia \\ Email : elisabethnurhaini@yahoo.com
}

\begin{abstract}
ABSTRAK
Tujuan penelitian ini adalah untuk mengetahui bentuk jaminan dalam perjanjian kredit dan eksekusi hak jaminan dalam penyelesaian kredit macet pada PT Bank Perkreditan Rakyat (BPR) Solider Pancur Batu Kabupaten Deli Serdang. Penelitian ini merupakan penelitian normatif-empiris, yang membutuhkan data primer dan data sekunder Analisis data dilakukan dengan cara pendekatan terhadap fakta-fakta di lapangan dan pendekatan perundang-undangan yang bersifat deskriptif. Hasil penelitian menunjukkan bahwa bentuk jaminan dalam perjanjian kredit pada PT Bank Perkreditan Rakyat (BPR) Solider Pancur Batu Kabupaten Deli Serdang disesuaikan dengan jenis kredit yang diajukan, dan eksekusi hak jaminan dalam penyelesaian kredit macet dimulai dengan melakukan mediasi jika gagal, dilakukan penarikan obyek jaminan untuk dijual secara bersama, sebaliknya apabila dalam tahap ini juga gagal, tahap akhir yang dilakukan adalah dengan cara pelelangan.

Kata kunci : eksekusi, hak jaminan, kredit macet, perjanjian kredit

\section{ABSTRACT}

The purpose of this study was to determine the form of collateral in the credit agreement and the execution of guarantee rights in the settlement of bad credit at PT Bank Perkreditan Rakyat (BPR) Solider Pancur Batu, Deli Serdang Regency. This research is a normative-empirical research, which requires primary data and secondary data. Data analysis is carried out by approaching the facts in the field and a descriptive statutory approach. The results show that the form of collateral in the credit agreement at PT Bank Perkreditan Rakyat (BPR) Solider Pancur Batu, Deli Serdang Regency is adjusted to the type of credit proposed, and the execution of collateral rights in the settlement of bad credit begins with mediation if it fails,withdrawal of the collateral object for sold collectively, on the other hand, if in this stage it also fails, the final stage that is done is by means of an auction.
\end{abstract}

Keywords : the execution, guarantee rights, bad credit, the credit agreement.

\section{A. PENDAHULUAN}

Perkreditan merupakan kegiatan yang paling penting bagi perbankan, karena kredit juga merupakan salah satu sumber dana penting untuk setiap jenis usaha. Ketatnya persaingan antar bank saat ini turut mendorong di Indonesia untuk lebih giat dalam mengembangkan usahanya baik peningkatan kualitas pelayanan maupun kualitas jasa.
Hubungan bisnis seperti ini merupakan hubungan hukum yang melahirkan hak dan kewajiban yang bertujuan untuk memperoleh keuntungan atau kekayaan yang terjadi karena kontrak atau perjanjian. jika perjanjian dipandang sebagai hubungan hukum yang antara

Eksekusi Hak Jaminan Dalam Penyelesaian Kredit Macet Pada PT. Bank Perkreditan Rakyat (BPR) Solider Pancur Batu, Kabupaten Deli Serdang

Oleh : Dr. Elisabeth N Butar-Butar, S.H., M.Hum 
dua orang yang bersepakat untuk menimbulkan akibat hukum. ${ }^{1}$

Setiap penyaluran kredit oleh tentu mengandung resiko, karena adanya keterbatasan kemampuan manusia dalam memprediksi masa yang akan datang, untuk itu bank harus merencanakan sedemikian rupa dan berusaha untuk menekan resiko munculnya kredit bermasalah. Pihak bank juga perlu menilai kelayakan usaha dari debitur dan juga diperlukan adanya pengelolaan dan pengawasan, sehingga kesinambungan usaha perbankan tetap terjaga. Dalam menyalurkan kredit kepada masyarakat tidak keseluruhan dana yang disalurkan tersebut dapat dikembalikan seluruhnya atau sebagaimana mestinya, maka hal inilah yang menjadi penyebab timbulnya kredit bermasalah. Kredit bermasalah dapat diartikan sebagai ketidak sanggupan debitur untuk melunasi pinjamannya kepada bank berupa angsuran pokok dari pinjaman beserta bunganya, serta biaya lain dimana mengalami kegagalan karena deviasi (penyimpangan) sehingga tidak sesuai dengan perjanjian yang telah disepakati yang akhirnya dapat membawa kerugian.

Kredit bermasalah timbul tidak dengan seketika melainkan secara bertahap dimana terjadi penurunan berbagai aspek yang dimiliki debitur yang berakhir dengan ketidak mampuan debitur membayar kreditnya. Mencari penyebab kredit bermasalah adalah sulit karena banyak faktor yang mempengaruhi baik yang bersifat intern maupun ekstern. Faktor ekstern "berasal dari luar perusahaan" seperti keadaan ekonomi, persaingan, bencana alam dan dari debitur itu sendiri. Sedangkan faktor intern "berasal dari dalam pihak

\footnotetext{
1 Sudikno Mertokusumo, 2007, Penemuan Hukum, Sebuah Pengantar, Liberty, Yogyakarta hlm. 110.
}

perusahaan" seperti kesalahan penilaian dalam pemberian kredit atau minimnya pengawasan dan pembinaan terhadap kredit yang disalurkan. Kredit bermasalah merupakan disebabkan berbagai faktor yang berkaitan satu sama lainnya, untuk itu harus segera mungkin mendapatkan penyelesaian karena dapat menyebabkan terganggunya kondisi bank

PT Bank Perkreditan Rakyat (BPR) Solider Pancur Batu Kabupaten Deli Serdang dalam memberikan kredit terhadap nasabahnya tetap berdasarkan prinsip kehati-hatian untuk menghindari risiko kredit bermasalah, Sebelum dimulainya kegiatan pemberian kredit diperlukan suatu analisis yang baik dan seksama terhadap semua aspek perkreditan yang dapat menunjang proses pemberian kredit, guna mencegah timbulnya suatu risiko kredit.

Pada dasarnya, kredit macet atau non performing loan merupakan kredit yang mengalami kesulitan pelunasan akibat adanya unsur-unsur kesengajaan atau karena kondisi di luar kemampuan debitur. Meskipun analisis kredit telah dilakukan, namun seringkali kredit yang disalurkan mengalami masalah karena debitur tidak mampu menyelesaikan kredit sebagaimana mestinya atau melampaui batas waktu yang ditentukan sesuai dengan perjanjian kredit yang telah disepakati bersama sehingga menyebabkan kredit macet. Setiap manajemen perusahaan perbankan tentu memiliki prosedur tersendiri untuk menangani jenis kredit yang bermasalah, yang tentunya dapat mengancam pendapatan dari perusahaan itu sendiri.

PT Bank Perkreditan Rakyat (BPR) Solider Pancur Batu Kabupaten Deli Serdang dalam mengatur kredit dituntut untuk benar-benar memperhatikan calon nasabahnya sesuai dengan prinsip lima $\mathrm{C}$ yaitu: (1) 
Character, (2) Capital, (3) Capacity, (4) Condition of Economy, dan (5) Collateral sehingga dapat memperkecil terjadinya kredit macet.

Kredit macet dapat dihindari dengan cara yaitu: sebelum memberikan kredit kepada nasabah perlu dilakukannya survei langsung ke lapangan oleh petugas bank, serta meninjau kelayakan penerima kredit, dan diperlukannya perhatian yang cermat serta memperhitungkan tingkat risiko yang akan dihadapi. Setelah kredit disetujui oleh pihak bank maka kewajiban dari nasabah adalah membayar pokok dan bunga yang dibebankan dalam jangka waktu yang telah ditetapkan..

Perjanjian kredit yang diberikan oleh bank mengandung risiko dalam pelaksanaannya, maka sebelum menyalurkan kreditu, bank harus memperhatikan asas kehati-hatian, di antaranya harus memprediksi kemungkinan terjadinya kredit macet sehingga perlu jaminan pelunasan atas kredit yang disalurkan. Pemberian jaminan dapat menjadi pengaman apabila di kemudian hari debitur tidak memenuhi kewajiban-kewajibannya. Berdasarkan Pasal 1131 dan Pasal 1132 KUH Perdata ditentukan bahwa segala kebendaan si berhutang, baik yang bergerak maupun yang tak bergerak, baik yang sudah ada maupun yang akan ada dikemudian hari, menjadi tanggungan untuk segala perikatan perseorangan.

Secara umum, jaminan dapat diartikan sebagai sesuatu hak atas kebendaan yang diberikan kepada kreditur sebagai jaminan atas pelunasan piutangnya yang menimbulkan keyakinan bahwa debitur akan melunasi kewajibannya berupa kewajiban yang dapat dinilai dengan uang yang timbul dari suatu perikatan. ${ }^{2}$

Dengan demikian, penyelesaian lebih lanjut akibat adanya kredit macet dalam penyaluran kredit adalah dengan melakukan eksekusi terhadap jaminan dalam perjanjian kredit. Oleh karena itu, agar terhindar dari kerugian, PT Bank Perkreditan Rakyat (BPR) Solider Pancur Batu Kabupaten Deli Serdang, juga menyalurkan kredit dengan meminta jaminan dari debitur, dan penyelesaian kredit macet. umumnya dilakukan dengan melaksanakan eksekusi terhadap hak jaminan.

Sebagai permasalahan dalam penelitian, sebagai dasar untuk melakukan penelitian adalah untuk mengetahui bentuk jaminan dalam perjanjian kredit pada PT Bank Perkreditan Rakyat (BPR) Solider Pancur Batu Kabupaten Deli Serdang, dan mengetahui pelaksanaan eksekusi hak jaminan tersebut dalam penyelesaian kredit macet pada PT Bank Perkreditan Rakyat (BPR) Solider Pancur Batu Kabupaten Deli Serdang,

\section{B. METODE PENELITIAN}

Penelitian ini merupakan penelitian normatif-empiris, yang membutuhkan data primer dan data sekunder. Penelitian hukum empiris merupakan penelitian hukum mengenai pemberlakuan atau implementasi ketentuan hukum (kodifikasi, undangundang atau kontrak) secara in action pada setiap peristiwa hukum tertentu yang terjadi di dalam masyarakat yang berfokus pada penerapan atau

\footnotetext{
2 Elisabeth Nurhaini Butar2012, Hukum Harta Kekayaan, Menurut Sistematika KUH Perdata dan Perkembangannya, PT Refika Aditama, Bandung, hlm. 67.
} 
implementasi ketentuan normatif pada peristiwa hukum tertentu. ${ }^{3}$

Alat yang digunakan untuk mengumpulkan data sekunder adalah studi dokumen, yaitu dengan cara mengindetifikasi, mengumpulkan dan mensistematisasi semua peraturan yang berkaitan dengan permasalahan. ${ }^{4}$ Untuk mendapatkan data primer, yaitu berupa fakta, digunakan teknik komunikasi, sedangkan untuk memperoleh data sekunder digunakan teknik atau studi dokumen.

Analisis data dilakukan dengan pendekatan terhadap fakta di lapangan dan pendekatan perundang-undangan yang bersifat deskriptif. Data yang kemudian di kumpulkan, baik secara sekunder maupun primer yang merupakan hasil dari studi dokumen dan wawancara kemudian data tersebut di oleh secara kualitatif. Kemudian dilakukan analisis secara normatif, logis, sistematis.

Normatif artinya dalam menganalisi data digunakan dengan memperhatikan peraturan yang berlaku, logis artinya dalam menganalis data tersebut selalu menggunakan logika dan tidak boleh bertentangan antara data yang satu dengan data yang lainnya. Sistematis artinya, dalam menganalisis data yang dinalisis harus tetap berada dalam sistem hukum yang berlaku. Setelah data dianalisis, selanjutnya disimpulkan dengan menggunakan metode deduktif dan induktif secara bersama-sama.

3 Abdulkadir Muhammad, 2004, Hukum dan PeneIitian Hukum, PT Citra Aditya Bakti, Bandung, hlm.34.

4 Elisabeth Nurhaini Butarbutar, 2018, Metode Penelitian Hukum, LangkahLangkah untuk Menemukan Kebenaran dalam Ilmu Hukum, PT Refika Aditama, Bandung, hlm. 141.

\section{C.PEMBAHASAN}

1. Jenis Jaminan dalam Perjanjian Kredit pada PT BPR Solider Pancur Batu

BPR Solider beroperasi pada tanggal 14 Februari 1998 sesuai dengan keputusan Menteri Keuangan No. Kep.560KM171997. Maksud dan tujuan berdirinya Bank Perkreditan Rakyat Solider Pancur Batu ini secara khusus adalah untuk menyediakan pembiayaan dalam pembangunan usaha masyarakat. Proses pemberian kredit dimulai dengan permohonan kredit.

Melakukan pinjaman kredit di suatu jasa perbankan merupakan suatu pilihan yang harus dilakukan oleh masyarakat mengingat pertumbuhan ekonomi yang semakin pesat sehingga meningkat pula nilai kebutuhan pokok setiap individu yang tidak dapat terpenuhi. Kredit menurut Pasal 1 butir 11 Undang-Undang Perbankan bahwa "Penyediaan uang atau tagihan yang dapat dipersamakan dengan itu, berdasarkan persetujuan atau kesepakatan pinjaman untuk melunasi utangnya setelah jangka waktu tertentu dengan pemberian bunga"

Hubungan bisnis ini merupakan hubungan hukum yang melahirkan hak dan kewajiban yang bertujuan untuk memperoleh keuntungan atau kekayaan. Hubungan bisnis dapat terjadi karena kontrak atau perjanjian dalam lapangan hukum harta kekayaan. Dengan demikian, hubungan bisnis merupakan akibat dari perjanjian dari pihak-pihak yang membuatnya.

Dalam undang-undang perbankan yang terbaru yaitu no 10 tahun 1998 Pasal 1 butir 4 menyebutkan bahwa Bank Perkreditan Rakyat (BPR) adalah bank yang melakukan kegiatan usaha secara konvensional atau berdasarkan prinsip syariah yang dalam kegiatannya tidak memberikan jasa dalam lalu lintas perdagangan.

Eksekusi Hak Jaminan Dalam Penyelesaian Kredit Macet Pada PT. Bank Perkreditan Rakyat (BPR) Solider Pancur Batu, Kabupaten Deli Serdang 
Kemungkinan resiko yang timbul dalam penyaluran kredit adalah terjadi transaksi pembayaran kembali yang atas kredit dalam kondisi tidak terbayar atau pembayaran kembali dari debitur tersendat, dengan kata lain ada suatu indikasi terjadi kredit bermasalah. Kondisi ini akan menimbulkan kinerja likuiditas PT BPR Solider Pancur Batu terganggu dan berakibat buruk sehingga akan menjadikan PT BPR Solider Pancur Batu tersebut beku operasi, oleh sebab itu dibutuhkan suatu pengawasan pada kegiatan kredit tersebut oleh pihak menejemen, dari awal proses kegiatan hingga penyelesaian kegiatan kredit tersebut.

Salah satu hal yang sangat penting dalam perjanjian kredit bank adalah mengenai jaminan bagi pihak yang meminjamkan atau pihak bank (lreditur) jaminan dalam kaitannya dengan kredit merupakan salah satu syarat untuk dapat dikabulkannya permohonan kredit. Jaminan disini tidak hanya barang tetap milik debitur, tetapi juga dapat berupa jaminan immaterial. Jaminan immaterial meliputi faktor-faktor yang menyangkut diri debitur yang harus dipertimbangkan dalam pemberian kredit. Sering terjadi dalam praktek adalah nasabah tidak menepati waktu yang diperjanjikan dalam mengembalikan pinjamannya dengan berbagai alasan, sehingga timbul kredit yang bermasalah.

Kurangnya kesadaran untuk menerapkan prinsip-prinsip perkreditan yang sehat dalam permohonan kredit sebagaimana mestinya seperti prinsip lima C yaitu Character, Capital, Capacity, Condition of Economy, dan Collateral, menjadi faktor penyebab terjadinya kredit macet secara umum. Collateral (jaminan) sebagai salah satu prinsip perkreditan yang harus diperhatikan pihak bank untuk mencegah terjadinya masalah dalam penyelesaian kredit macet. Jaminan yang diberikan oleh calon debitur akan diikat dengan suatu hak atas jaminan sesuai dengan jaminan yang diserahkan kepada pihak bank, jaminan tersebut dapat diambil alih, dijual atau dilelang oleh bank setelah mendapatkan pengesahan dari pengadilan. Jumlah maksimal kredit dibandingkan dengan nilai jaminan yaitu sekitar $60 \%$.

Pada hakekatnya, fungsi jaminan adalah sebagai pengaman apabila di kemudian hari debitur tidak memenuhi kewajiban-kewajibannya. Berdasarkan Pasal 1131 dan Pasal 1132 KUH Perdata ditentukan bahwa segala kebendaan si berhutang, baik yang bergerak maupun yang tak bergerak, baik yang sudah ada maupun yang akan ada dikemudian hari, menjadi tanggungan untuk segala perikatan perseorangan.

UU Perbankan dengan tegas menyebutkan bahwa suatu bank tidak diperbolehkan memberikan kredit tanpa suatu perjanjian secara tertulis. ${ }^{5}$ Dengan demikian, perjanjian kredit merupakan suatu syarat utama bagi debitur untuk mendapatkan kredit dari bank yang bertujuan sebagai alat bukti bagi para pihak yang terkait dengan kredit tersebut. $^{6}$

Dalam hal ini tentu saja, debitur mengajukan permohonan kredit secara tertulis dengan melengkapi dokumen yang disyaratkan bank yaitu:

1) Fotocopy KTP dan Kartu Keluarga,

2) Pas foto,

3) Fotocopy Akta pendirian berikut seluruh perubahannya

5 Widjanarto, 2003, Hukum dan Ketentuan Perbankan Di Indonesia, Grafiti, Jakarta , h. 101 .

6 Sentosa Sembiring , 2012, Hukum Perbankan Edisi Revisi, CV. Mandar Maju, Bandung, h. 194 
4) Fotocopy perizinan usaha, yaitu NPWP, SIUP, dan SITU,

5) Fotocopy dokumen jaminan (sertifikat tanah, BPKB, Surat Toko, lainnya),

6) Data-data keuangan (Neraca Dan Laporan laba rugi),

7) Dokumen pendukung lainnya Berdasarkan hasil penelitian, jenis jaminan didasarkan kepada jenis kredit yang disalurkan pada Bank Perkreditan Rakyat Solider Pancur Batu sebagai mana disebutkan dalam tabel 1.

\begin{tabular}{|c|c|c|c|}
\hline No & $\begin{array}{l}\text { Jenis } \\
\text { Kredit }\end{array}$ & $\begin{array}{l}\text { Jenis } \\
\text { Jaminan }\end{array}$ & $\begin{array}{l}\text { Tujuan } \\
\text { Kredit }\end{array}$ \\
\hline 1. & $\begin{array}{l}\text { Kredit } \\
\text { Usaha } \\
\text { Masyarak } \\
\text { at (KMK) }\end{array}$ & $\begin{array}{l}\text { SHM/SHGB/ } \\
\text { Akta } \\
\text { Camat/Akta } \\
\text { Notaris/BPKB }\end{array}$ & $\begin{array}{l}\text { mendorong } \\
\text { percepatan } \\
\text { Usaha } \\
\text { Mikro }\end{array}$ \\
\hline 2. & $\begin{array}{l}\text { Kredit } \\
\text { Sejahtera } \\
\text { Solider } \\
\text { (KSS) }\end{array}$ & $\begin{array}{l}\text { Proyek yang } \\
\text { dibiayai }\end{array}$ & $\begin{array}{l}\text { untuk } \\
\text { keperluan } \\
\text { pembelian } \\
\text { Kapling,/pe } \\
\text { mbangunan } \\
\text { /renovasi } \\
\text { rumah } \\
\text { tinggal, } \\
\text { ruko. }\end{array}$ \\
\hline 3 , & $\begin{array}{l}\text { Kredit } \\
\text { Modal } \\
\text { Kerja } \\
(\text { KMK) } \\
\text { untuk } \\
\text { Kontrakto } \\
\text { r }\end{array}$ & $\begin{array}{l}\text { Proyek yang } \\
\text { dibiayai }\end{array}$ & $\begin{array}{l}\text { membantu } \\
\text { modal } \\
\text { kerja } \\
\text { pembiayaa } \\
\text { n proyek }\end{array}$ \\
\hline 4. & $\begin{array}{l}\text { Kredit } \\
\text { Multi } \\
\text { Guna } \\
\text { (KMG) }\end{array}$ & $\begin{array}{l}\text { Kendaraan } \\
\text { bermotor roda } \\
\text { dua/atau roda } \\
\text { empat, tanah } \\
\text { dan bangunan, } \\
\text { tanah tanpa } \\
\text { bangunan, } \\
\text { deposito } \\
\text { berjangka PT. } \\
\text { BPR Solider }\end{array}$ & $\begin{array}{l}\text { untuk } \\
\text { membiayai } \\
\text { kebutuhan } \\
\text { apa saja } \\
\text { yang } \\
\text { bersifat } \\
\text { konsumtif }\end{array}$ \\
\hline
\end{tabular}

Sumber : data dianalisis

Cek Agunan/Usaha Setelah pihak bank memeriksa kelengkapan dokumen tersebut, pihak bank melanjutkan proses pemberian kredit dengan melakukan cek agunan atau usaha debitur, yang bertujuan untuk mengetahui modal calon debitur. Setelah semuanya lancar pihak bank akan melakukan penilaian terhadap agunan yang dijamin oleh calon debitur, misalnya SK karyawan atau surat-surat tanah atau sertifikat rumah.

Kemungkinan resiko yang timbul dalam penyaluran kredit adalah terjadi transaksi pembayaran kembali yang atas kredit dalam kondisi tidak terbayar atau pembayaran kembali dari debitur tersendat, dengan kata lain ada suatu indikasi terjadi kredit bermasalah. Kondisi ini akan menimbulkan kinerja likuiditas PT BPR Solider Pancur Batu terganggu dan berakibat buruk sehingga akan menjadikan PT BPR Solider Pancur Batu tersebut beku operasi, oleh sebab itu dibutuhkan suatu pengawasan pada kegiatan kredit tersebut oleh pihak menejemen, dari awal proses kegiatan hingga penyelesaian kegiatan kredit tersebut.

Berdasarkan hasil wawancara yang dilakukan, diketahui bahwa kredit macet disebabkan oleh empat faktor yaitu :

1) Kurangnya ketelitian dari pihak petugas dalam analisa penyaluran kredit. Hal ini dipengaruhi oleh adanya target yang ingin dicapai sehingga mendorong pihak petugas kredit menempuh jalan yang tidak sesuai dengan ketentuan dalam menyalurkan kredit,

2) kurang selektifnya dalam memilih calon debitur dan mengabaikan kondisi debitur, yang menyebabkan bank kekurangan informasi berkaitan dengan kemampuan debitur dalam mengembalikan pinjamannya

3) Adanya itikad tidak baik dari petugas bank yang memanfaatkan keberadaan bank untuk 
kepentingan pribadi, di mana salah satu dari petugas bank memiliki hubungan bisnis dengan debitur maupun dengan calon debitur sehingga dengan sengaja melanggar ketentuan yang diterapkan oleh bank terutama ketentuan dalam menyalurkan kredit Walaupun pihak debitur tidak memenuhi syarat untuk mendapatkan kredit, tetapi pegawai tetap memberikan kredit padanya.

4) kurangnya pengawasan kredit yang dilakukan baik sebelum maupun setelah pemberian kredit yang diberikan kurang memadai, sehingga bank tidak dapat mendeteksi sedini mungkin terjadinya penyimpangan dalam keterlambatan melakukan langkah-langkah pencegahan terjadinya kredit bermasalah. Kurangnya pengawasan yang dilakukan dapat menyebabkan bank kekurangan informasi yang berkaitan dengan kondisi usaha debitur, dimana dengan usaha debitur mengalami kebangkrutan maka akan mempengaruhi kelancaran pembayaran; sehingga pihak bank akan mengalami kredit bermasalah.

Kurangnya ketelitian dari pihak petugas dalam analisis penyaluran kredit sangat mempengaruhi terjadinya kegagalan pembayaran. Hal ini disebabkan karena adanya target yang ingin dicapai sehingga mendorong pihak petugas kredit menempuh jalan yang tidak sesuai dengan ketentuan dalam menyalurkan kredit, Kewajiban ini, memaksa untuk mengejar target itu dengan berbagai cara karena adanya ancaman atau sanksi jika target tersebut tidak dipenuhi di samping tidak mendapatkan bonus ancaman diberhentikan pun akan terjadi. Target kredit seakan-akan menjadi momok yang menakutkan bagi pihak karyawan, sehingga membuat karyawan berupaya dalam menyalurkan kredit demi target yang ditetapkan tersebut dapat terpenuhi.

Pihak bank menetapkan target kredit yang harus ditempuh oleh karyawan, tujuan ditetapkannya target kredit tersebut bukan semata-mata untuk mengejar keuntungan semata, namun juga untuk membuat karyawan lebih semangat untuk lebih giat bekerja. Dengan ditetapkannya target akan membuat karyawan bekerja dengan giat.

Kredit bermasalah adalah kredit yang dalam pelaksanaannya belum mencapai/memenuhi target yang diinginkan oleh pihak bank, kredit yang memiliki kemungkinan timbulnya resiko dikemudian hari bagi bank dalam arti luas, kredit golongan perhatian khusus, kurang lancar, diragukan, dan macet serta golongan lancar yang berpotensi menunggak. $^{7}$

Berbeda dengan pendapat Sutojo ${ }^{8}$ kredit dapat dikatakan bermasalah apabila terjadi keterlambatan pembayaran bunga dan/atau kredit induk lebih dari 90 hari sejak tanggal jatuh temponya, tidak dilunasi sama sekali, diperlukan negosiasi kembali atas syarat pembayaran kembali kredit dan bunga yang tercantum dalam perjanjian kredit.

Dari hasil penelitian diketahui bahwa adanya dorongan dari pihak bank yang menyarankan untuk meminjam uang, padahal pada saat itu debitur tidak begitu sangat membutuhkan akan kredit tersebut, dan petugas bank juga tidak begitu memperhatikan kelayakan

\footnotetext{
7 Rivai Veithzal \& Anria Permata Veithzal, Credit Management Handbook, PT Raja Grafindo Persada, 2006, hlm. 476.

8 Sutojo, Siswanto, Menangani Kredit Bermasalah, PT Damar Mulia Pustaka, Jakarta, 2008, hlm. 13.
} 
debitur dalam memperoleh kredit dilatarbelakangi adanya rasa kekeluargaan dari salah satu pegawai bank. yang dengan sengaja memberikan sejumlah kredit kepada debitur yang merupakan keluarganya, walaupun debitur tersebut tidak memenuhi syarat untuk mendapatkan kredit, namun tetap kredit tersebut dicairkan, dan pada akhirnya kredit tersebut tidak dibayar oleh debitur tersebut, sehingga menyebabkan kredit macet.

Pada umumnya, petugas bank melakukan pengawasan kredit pada debitur, namun pengawasan itu cuma dilakukan pada pertamanya saja pada saat sebelum debitur menerima kredit. kredit yang diperoleh debitur digunakan untuk membuka usaha, namun usaha debitur tersebut mengalami kebangkrutan sehingga menyebabkan terjadinya keterlambatan dalam pembayaran kredit.

Menurut hasil penelitian, terjadinya kredit macet pada PT BPR Solider Pancur Batu dikarenakan usaha yang dijalankan debitur dengan mempergunakan modal dari pinjaman bank mengalami kerugian yang menyebabkan debitur tidak dapat melunasi kreditnya sesuai dengan jangka waktu yang telah ditentukan. Penyebab debitur tidak dapat melunasi kewajibannya untuk membayar kreditnya dikarenakan usaha yang digeluti debitur mengalami kerugian, yang membuat debitur tidak mempunyai kemampuan untuk membayar kewajibannya karena tidak memiliki penghasilan lain yang dapat dipergunakan untuk membayar angsuran kredit. Dengan dibiarkannya keadaan seperti ini terus berlanjut dan tidak ditangani dengan tepat, akan menyebabkan kredit macet bagi bank.

Dari hasil wawancara yang dilakukan pada PT BPR Solider Pancur Batu, diketahui bahwa kredit yang diperoleh debitur digunakan untuk membuka usaha, namun usaha debitur tersebut mengalami kebangkrutan sehingga menyebabklan terjadinya keterlambatan dalam pembayaran kredit, dan debitur tidak memiliki pekerjaan lain selain lain usaha yang gelutinya tersebut, debitur cuma menghandalkan penghasilan dari usaha yang kelolanya tersebut untuk membayar angsuran kredit.

Upaya yang dilakukan untuk mengatasi kredit macet pada PT BPR Solider Pancur Batu yaitu dengan melakukan beberapa cara pendekatan yang dapat dipertimbangkan dalam upaya penyelematan kredit bermasalah yaitu:

1) restructuring,

2) rescheduling,

3) Penyitaan jaminan, dan

4) Penghapusan (penghapusan piutang).

Kredit

Dampak yang ditimbulkan dari kredit macet yang terjadi pada PT BPR Solider Pancur Batu, terdapat lima dampak yang paling dirasakan yaitu :

1) Pendapatan menurun,

2) Perputaran kas menjadi terganggu,

3) Tingkat Kesehatan Bank,

4) Modal Bank, dan

5) Turunnya kepercayaan masyarakat.

Langkah-langkah yang dilakukan PT BPR Solider Pancur Batu untuk menyelesaian kredit bermasalahnya yang disebabkan oleh faktor ekstern :

1) Melakukan peringatan dengan mengirimkan surat peringatan (SP 1) sampai (SP 3) kepada debitur untuk segera membayar tunggakan kredit yang telah terjadi.

2) Penagihan, PT BPR Solider Pancur Batu melakukan Penagihan kepada debitur, apabila debitur tidak sanggup membayar 
tunggakan kreditnya, maka pihak PT BPR Solider Pancur Batu akan menghubungi pihak penanggung jawab yang ikut serta menandatangani perjanjian kredit.

3) Restrukturisasi kredit, PT BPR Solider Pancur Batu memberikan solusi kepada debitur untuk menyelesaikan kredit bermasalahnya dengan cara memperpanjang jangka waktu kreditnya, dan melakukan penambahan modal usaha debitur.

4) Penarikan, Apabila nasabah tidak sanggup lagi membayar tunggakan kreditnya maka PT BPR Solider Pancur Batu akan melakukan penarikan agunan debitur.

5) Pelelangan Setelah melakukan penarikan maka PT BPR Solider Pancur Batu melakukan pelelangan agunan untuk melunasi tunggakan kredit debitur.

Jenis jaminan dalam perjanjian kredit pada PT BPR Solider Pancur Batu tergantung pada jenis kredit yang disalurkan. Kredit Usaha Masyarakat (KMK) yang bertujuan untuk mendorong percepatan Usaha Mikro mewajibkan Sertifikat Hak Milik/Sertifikat Hak Guna Bangunan/Akta Camat/Akta Notaris/BPKB. Kredit Sejahtera Solider (KSS) yang bertujuan untuk keperluan pembelian

Kapling,/pembangunan/renovasi rumah tinggal, ruko, jaminannya dapat dalam bentuk proyek yang dibiayai. Kredit Modal Kerja (KMK) yang bertujuan untuk kontraktor dalam membantu modal kerja pembiayaan proyek mewajibkan dalam bentuk proyek yang dibiayai.

Sesuai dengan ketentuan Pasal 1331 KUH Perdata, maka kekayaan debitur, baik bergerak maupun tidak bergerak, baik yang sudah ada maupun yang aka nada menjadi jaminan atas semua utang yang dibuatnya. Prinsip ini menjadi dasar bagi perbankan untuk mewujudkan salah satu prinsip penyaluran kredit yang mengharuskan pihak perbankan menerapkan prinsip kehati-hatian.Jika diperhatikan dalam ketentuan Pasal 8 UU Perbankan mengartikan jaminan tersebut sebagai suatu keyakinan atas kemampuan dan kesanggupan debitur untuk melunasi hutngnya sesuai dengan yang diperjanjikan. Pengertian jaminankredit diartikan juga sebagai tindakan penyerahan kekayaan atau pernyataan keasanggupan seseorang untuk melakukan pembayaran kembali utang.

\section{Eksekusi Hak Jaminan dalam} Penyelesaian Kredit Macet

Dalam dunia perbankan sering ditemui kredit macet yaitu risiko yang terjadi dari penyaluran kredit bank, kredit bermasalah menggambarkan suatu situasi dimana pengembalian kredit mengalami risiko kegagalan, bahkan cenderung menuju atau mengalami kerugian; sehingga diperlukan kewaspadaan pihak bank dalam semua aktivitasnya terutama dalam penyaluran kredit. Kredit macet sulit untuk dihindari namun bank harus mampu memperkecil kemungkinan risiko terjadinya kredit bermasalah sehingga dapat memberikan keuntungan bagi pihak bank.

Ketentuan Bank Indonesia No. 31/147/KEP/DIR tanggal 12 November 1988, untuk melihat aktiva produktif bank dan seberapa jauh kredit bermasalah terdapat pada bank tersebut dinilai berdasarkan kolektibilitas kreditnya. Kolektibilitas kredit adalah keadaan pembayaran pokok, angsuran pokok, dan bunga kredit oleh nasabah serta tingkat kemungkinan diterimanya kembali dana yang dinamkan dalam surat-surat berharga atau penanaman 
lainnya. Dengan melihat kolektibilitas kredit dapat dinilai kualitas kredit yang diberikan.

Hasil penelitian menunjukkan bahwa kredit macet disebabkan oleh empat faktor yaitu kurangnya ketelitian dari pihak petugas dalam analisis penyaluran kredit. Hal ini dipengaruhi oleh adanya target yang ingin dicapai sehingga mendorong pihak petugas kredit menempuh jalan yang tidak sesuai dengan ketentuan dalam menyalurkan kredit, kurang selektifnya dalam memilih calon debitur dan mengabaikan kondisi debitur, yang menyebabkan bank kekurangan informasi berkaitan dengan kemampuan debitur dalam mengembalikan pinjamannya.

Adanya itikad tidak baik dari petugas bank yang memanfaatkan keberadaan bank untuk kepentingan pribadi, di mana salah satu dari petugas bank memiliki hubungan bisnis dengan debitur maupun dengan calon debitur sehingga dengan sengaja melanggar ketentuan yang diterapkan oleh bank terutama ketentuan dalam menyalurkan kredit Walaupun pihak debitur tidak memenuhi syarat untuk mendapatkan kredit, tetapi pegawai tetap memberikan kredit padanya, dan kurangnya pengawasan kredit yang dilakukan baik sebelum maupun setelah pemberian kredit yang diberikan kurang memadai, sehingga bank tidak dapat mendeteksi sedini mungkin terjadinya penyimpangan dalam keterlambatan melakukan langkah-langkah pencegahan terjadinya kredit bermasalah. serta kurangnya pengawasan yang dilakukan dapat menyebabkan bank kekurangan informasi yang berkaitan dengan kondisi usaha debitur, dimana dengan usaha debitur mengalami kebangkrutan maka akan mempengaruhi kelancaran pembayaran; sehingga pihak bank akan mengalami kredit bermasalah.

Faktor-faktor penyebab kredit macet terdiri dari dua faktor intern dan faktor ekstern. Faktor intern terdiri dari empat variable, yaitu:

a. kegagalan mengelola usaha,

b. kebijakan perkreditan yang kurang menunjang,

c. kelemahan sistem dan prosedur penilaian kredit, dan

d. pemberian dan pengawasan yang menyimpang dari prosedur.

Faktor ekstern terdiri dari tiga variabel yaitu:

1) lingkungan usaha debitur yang kurang menunjang

2) musibah seperti kebakaran, bencana alam, dan

3) persaingan antara lembaga keuangan.

Jadi diperlukan penanganan yang sistematis dan berkelanjutan untuk mengatasi penyebab terjadinya kredit macet. Dalam tahap mengeksekusi jaminan yang telah dibebankan dengan Fidusiia ketika debitur dalam hal ini Pemberi Fidusia cidera janji, berdasarkan keterangan yang diperoleh melalui hasil wawancara, sebelumnya belum pernah melakukan eksekusi terhadap Jaminan Fidusia. karena selama ini yang menjadi nasabah debitur PT BPR Solider Cabang Pancur Batu, menjalankan prestasi atau kewajiban sesuai dengan apa yang telah diperjanjikan. Eksekusi merupakan pelaksanaan putusan pengadilan yang telah mempunyai kekuatan hukum tetap. ${ }^{9}$ Likuidasi jaminan, apa bila kredit yang diberikan sudah tidak bisa lagi diselesaikan, maka jalan terakhir adalah likuidasi jaminan.

Proses pelaksanaan eksekusi diatur dalam Pasal 196HIR/ Pasal 206

9 Zainal Asikin, 2015, Hukum Acara Perdata di Indonesia, Cetakan Kedua, Predana Media Group, Jakarta, hlm. 146.

Eksekusi Hak Jaminan Dalam Penyelesaian Kredit Macet Pada PT. Bank Perkreditan Rakyat (BPR) Solider Pancur Batu, Kabupaten Deli Serdang

Oleh : Dr. Elisabeth N Butar-Butar, S.H., M.Hum 
Rbg yang menentukan, jika pihak yang dikalahkan tidak mau atau lalai untuk memenuhi isi putusan itu dengan damai, maka pihak yang menang memasukkan permintaan, baik dengan lisan, maupun dengan surat, kepada Ketua Pengadilan Negeri yang memutuskan perkara dalam tingkat pertama. Eksekusi dilakukan atas perintah dan di bawah pinpinan Ketua Pengadilan Negeri yang bersangkutan sebagaimana ditentukan pada Pasal 195 ayat (1) HIR/Pasal 206 ayat (1) Rbg, dan untuk menjalankan putusan itu, Ketua Pengadilan Negeri menyuruh memanggil pihak yang dikalahkan serta memperingatkan, supaya ia memenuhi keputusan itu di dalam tempo yang ditentukan oleh ketua, yang selama-lamanya delapan hari."

Suatu putusan yang telah memperoleh kekuatan hukum tetap dapat dilaksanakan secara sukarela oleh pihak yang dikalahkn, dan apabila pihak yng dikalahkan tidak mau melaksanakan putusan hakim secara sukarela, maka dapat dilakukan melalui bantuan pengadilan untuk melaksanakan putusan secara paksa. Oleh karena putusan hakim yang mempunyai kekuatan eksekutorial diartikan sebagai kekuatan untuk dilaksanakannya apa yang ditetapkan dalam putusan itu secara paksa oleh alat-alat negara. ${ }^{10}$

Adapun likuidasi yang dilakukan dengan tahapan sebagai berikut :

1. teguran, ini dilakukan apabila debitur tidak dapat melunasi piutangnnya pada saat jatuh tempo,

2. somasi, maka meminta bantuan pada Pengadilan Negeri untuk melayangkan somasi.

10 Sudikno Mertokusumo, 2013, Hukum Acara Perdata Indonesia, Edisi Revisi, Yogyakarta : Cahaya Atma Pustaka, hlm.2.
3. gugatan, bila debitur berkeberatan untuk dieksekusi jaminan maka dapat menggunakan eksekusi jaminan melalui suatu gugatan terhadap debitur untuk memperoleh putusan Pengadilan Negeri sebagai dasar untuk eksekusi jaminan tersebut.

Berdasarkan hasil penelitian, nasabah yang cidera janji tidak dalam tahap yang serius, sehingga dapat diselesaikan secara mediasi yang dilakukan pihak PT BPR Solider Cabang Pancur Batu dengan pihak debitur agar segera melakukan prestasinya sesuai dengan yang telah diperjanjikan. Namun dengan nasabah yang cidera janji dengan tahap yang serius, dalam hal ini kredit macet, pihak PT BPR Solider Cabang Pancur Batu memiliki prosedur dan tahapan dalam melakukan suatu eksekusi, yaitu dimulai dengan melakukan mediasi. Mediasi bertujuan untuk penyelesaikan permasalahan tersebut secara kekeluargaan. Jika dalam tahap ini ternyata gagal, kemudian tahap selanjutnya pihak PT BPR Solider Cabang Pancur Batu akan melakukan eksekusi berupa penarikan obyek jaminan dan setelah itu akan menjual obyek jaminan dengan cara penjualan secara bersama. Penjualan secara bersama ini adalah kedua pihak samasama berusaha untuk menjual obyek jaminan. Hasil dari penjualan tersebut nantinya akan digunakan untuk membayar sisa utang debitur terhadap PT BPR Solider Cabang Pancur Batu.

Apabila hasil penjualan tersebut lebih dari sisa hutang debitur terhadap bank, maka sisa hasil penjualan akan dikembalikan kepada debitur, sebaliknya apabila dalam tahap ini juga gagal, tahap akhir yang dilakukan adalah dengan cara pelelangan. Jika hasil dalam proses pelelangan ini melebihi sisa hutang debitur terhadap 
PT BPR Solider Cabang Pancur Batu, maka sisa hasil pelelangan akan dikembalikan kepada debtor, namun apabila dari pelelangan ternyata kurang dari sisa hutang debitur terhadap PT BPR Solider Cabang Pancur Batu, maka sisa hutang tersebut masih dalam tanggung jawab debitur sesuai dengan perjanjian yang telah disepakati bersama.

\section{KESIMPULAN DAN SARAN}

Dari uraian-uraian tersebut di atas terhadap pembahasan atas permasalahan yang diajukan, maka ditarik kesimpulan sebagai berikut :

1. Bentuk jaminan dalam perjanjian kredit pada PT Bank Perkreditan Rakyat (BPR) Solider Pancur Batu Kabupaten Deli Serdang disesuaikan dengan jenis kredit yang diajukan di mana bentuk jaminan dapat merupakan keyakinan atas kemampuan dan kesanggupan debitur untuk melunasi hutngnya sesuai dengan yang diperjanjikan.

2. Eksekusi hak jaminan dalam penyelesaian kredit macet dimulai dengan melakukan mediasi jika gagal, dilakukan eksekusi berupa penarikan obyek jaminan dan setelah itu akan menjual obyek jaminan dengan cara penjualan secara bersama, sebaliknya apabila dalam tahap ini juga gagal, tahap akhir yang dilakukan adalah dengan cara pelelangan.

Berdasarkan temuantemuan hasil pembahasan sebagaimana telah disimpulkan di atas, maka disarankan:

1. Hendaknya dalam memberikan kredit pihak petugas kredit lebih teliti dalam memperhatikan nasabahnya dengan meningkatkan monitoring dan pengawasan terhadap kredit yang diberikan baik mengenai manajemen maupun keadaan debitur, sebelum kredit diberikan pihak bank memperhatikan kriteria calon nasabah.

2. Bagi peneliti lain yang berminat untuk mendalami bidang manajemen keuangan terkait kredit macet diharapkan untuk melakukan penelitian lebih lanjut mengenai faktor-faktor yang yang menyebabkan terjadinya kredit macet dengan menggunakan metode yang sama pada Bank yang berbeda.

\section{DAFTAR PUSTAKA}

Asikin, Zainal 2015, Hukum Acara Perdata di Indonesia, Cetakan Kedua, Predana Media Group, Jakarta.

Asser, 1991, Pengajian Hukum Perdata Belanda, Jilid II Hukum Perikatan, Bagian Pertama Perikatan, Dian Rakyat, Jakarta.

Butarbutar, Elisabeth Nurhaini, 2018, Metode Penelitian Hukum, Langkah-Langkah untuk Menemukan Kebenaran dalam Ilmu Hukum, PT Refika Aditama, Bandung.

Hukum Harta Kekayaan, Menurut Sistematika KUH Perdata dan Perkembangannya, PT Refika Aditama, Bandung.

Mertokusumo, Sudikno, 2013, Hukum Acara Perdata Indonesia, Edisi Revisi, Cahaya Atma Pustaka, Yogyakarta.

---------------, 2007, Menemukan Hukum, Suatu Pengantar, Liberty, Yogyakarta.

Sembiring, Sentosa, 2012, Hukum Perbankan Edisi Revisi, CV. Mandar Maju, Bandung. 
Siswanto, Sutojo, 2008, Menangani Kredit Bermasalah, PT Damar Mulia Pustaka, Jakarta

Subekti, R., R. Tirtosudibio, 1986, Kitab Undang-undang Hukum Perdata, Cetakan Keduapuluhlima, PT Pradnya Paramita, Jakarta.

Veithzal, Rivai, \& Anria Permata Veithzal, 2006, Credit Management Handbook, PT Raja Grafindo Persada, Jakarta.

Widjanarto, 2003, Hukum dan Ketentuan Perbankan Di Indonesia, Grafiti, Jakarta. 